\title{
Flood risk management for schools in the lowlands of Tokyo, Japan
}

 \\ ${ }^{I}$ Nihon University, Japan \\ ${ }^{2}$ Chuo College of Technology, Japan
}

\begin{abstract}
The motivation for this study was the Great East Japan Earthquake of March 2011. Many schools and students experienced adverse effects during this disaster, most of which were attributable to the subsequent tsunami. This has highlighted the need to improve disaster reduction measures and disaster management in schools to ensure the safety of the students. Communities where children live must be made safe, and taking measures to ensure their safety in the event of a disaster is of the highest priority.

In recent years, the frequency of large-scale floods due to extreme weather events has increased. These floods have resulted in severe damage and have claimed many lives. Schools are often used as temporary accommodation for victims of flooding disasters. In this paper, the disaster management plans for community facilities were investigated, in relation to government policy, with a survey of current conditions. The areas targeted for the survey were lowland areas of Tokyo that have been impacted by flooding in the past. The policies for flood prevention of the Japanese government and the Tokyo Metropolitan government have been discussed by a team of experts in the past, but these policies must be continually analyzed and updated.

It was clear from the survey results that current flooding prevention measures in community facilities are insufficient. To reduce the risk of damage and loss of life due to disasters, it is necessary to manage resources such as disaster medical assistance teams and other emergency services. Guidance should also be provided for the building and planning of cities and towns to prevent flooding, shelters should be established with set capacities and secure evacuation routes, and initiatives should be implemented to increase public consciousness of the
\end{abstract}


risks posed by flooding. Moreover, disaster prevention education for managers and staff in factories, hospitals, and schools must be further improved.

Keywords: schools, lowlands, disaster reduction measures, disaster management, community facilities, emergency supplies.

\section{Introduction}

In Japan, schools are required to educate pupils on safety measures related to disasters, traffic accidents and other relevant hazards. It is important to be aware of the risk from natural disasters and take preemptive measures to safeguard public safety and private property. Approximately 1,000 students were reported dead or missing in the wake of the Great East Japan Earthquake of 2011. However, it was estimated that approximately 3,000 elementary and junior high school students survived because of the education they received on tsunami safety measures [1].

Schools are responsible both for their student's safety education and for preparing disaster response/prevention plans. Disaster prevention measures for improving the resilience of structures such as river embankments and sewers have been carried out in urban areas. However, with increased urbanization, the natural resilience of the land decreases, making urban areas vulnerable to inundation after torrential rain. It is therefore necessary for schools to determine suitable evacuation routes based on local geography and the characteristics of potential disasters.

\section{Lowlands of Tokyo}

Japan has a land area of $377,972.28 \mathrm{~km}^{2}$ and consists of 47 prefectures as shown in Figure 1. The Tokyo Metropolis is the capital of Japan and its largest city. The land area of the Tokyo Metropolis is $2188.67 \mathrm{~km}^{2}$, which is about $6 \%$ of the total land area of Japan, as shown in Figure 2 [2]. The lowlands of Tokyo are located in the eastern area of the Tokyo Metropolis, and are surrounded by the Arakawa and Edogawa rivers. The Arakawa, Katsushika, Adachi, Edogawa, Sumida and Koto wards have jurisdiction over this area, as shown in Figure 3 [3]. These areas have repeatedly suffered from storm surges and flooding in the past. Embankments have been installed along the Arakawa and Edogawa rivers, in addition to tributaries such as the Sumida and Nakagawa rivers, in order to protect against storm surges and other hazards. The Tokyo Metropolis has a population of about 13,500,000 people and 6,890,000 households, as of 2015 . Table 1 shows that about 2,800,000 people live in the lowlands of Tokyo [4]. The population of Japan is about $126,940,000$ in 2015 . Thus, about $10 \%$ of the population of Japan live in the Tokyo Metropolis, and around $20 \%$ of these live in the lowlands of Tokyo. And the total land area of the Arakawa, Katsushika, Adachi, Edogawa, Sumida and Koto wards is about $202 \mathrm{~km}^{2}(9.2 \%)$ as shown in Table 2 [5]. 




Figure 1: Map of Japan.

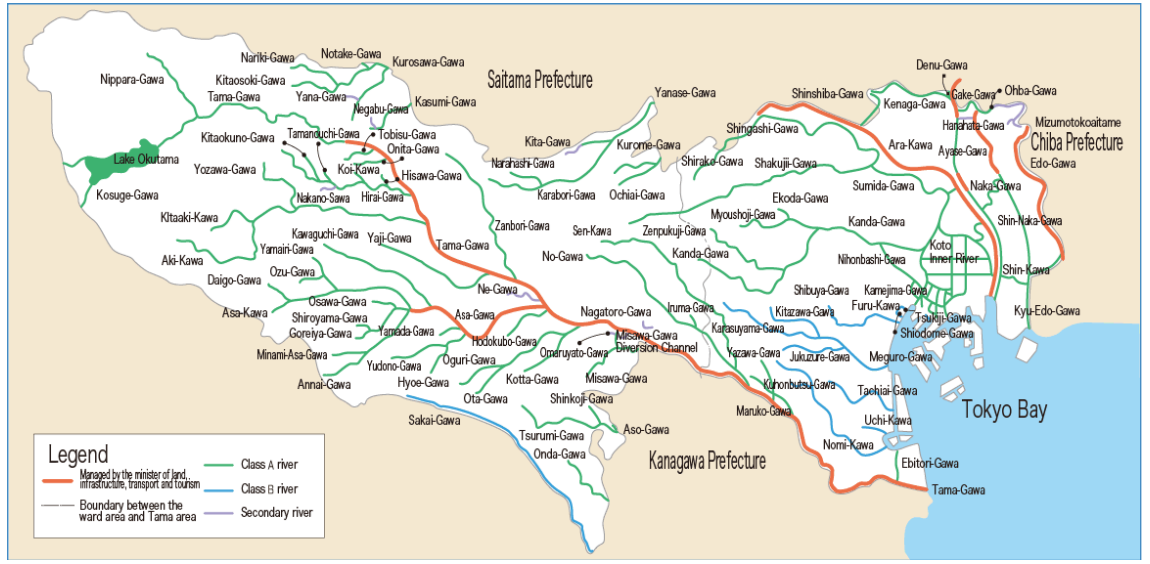

Figure 2: Rivers in the Tokyo Metropolitan area [2]. 


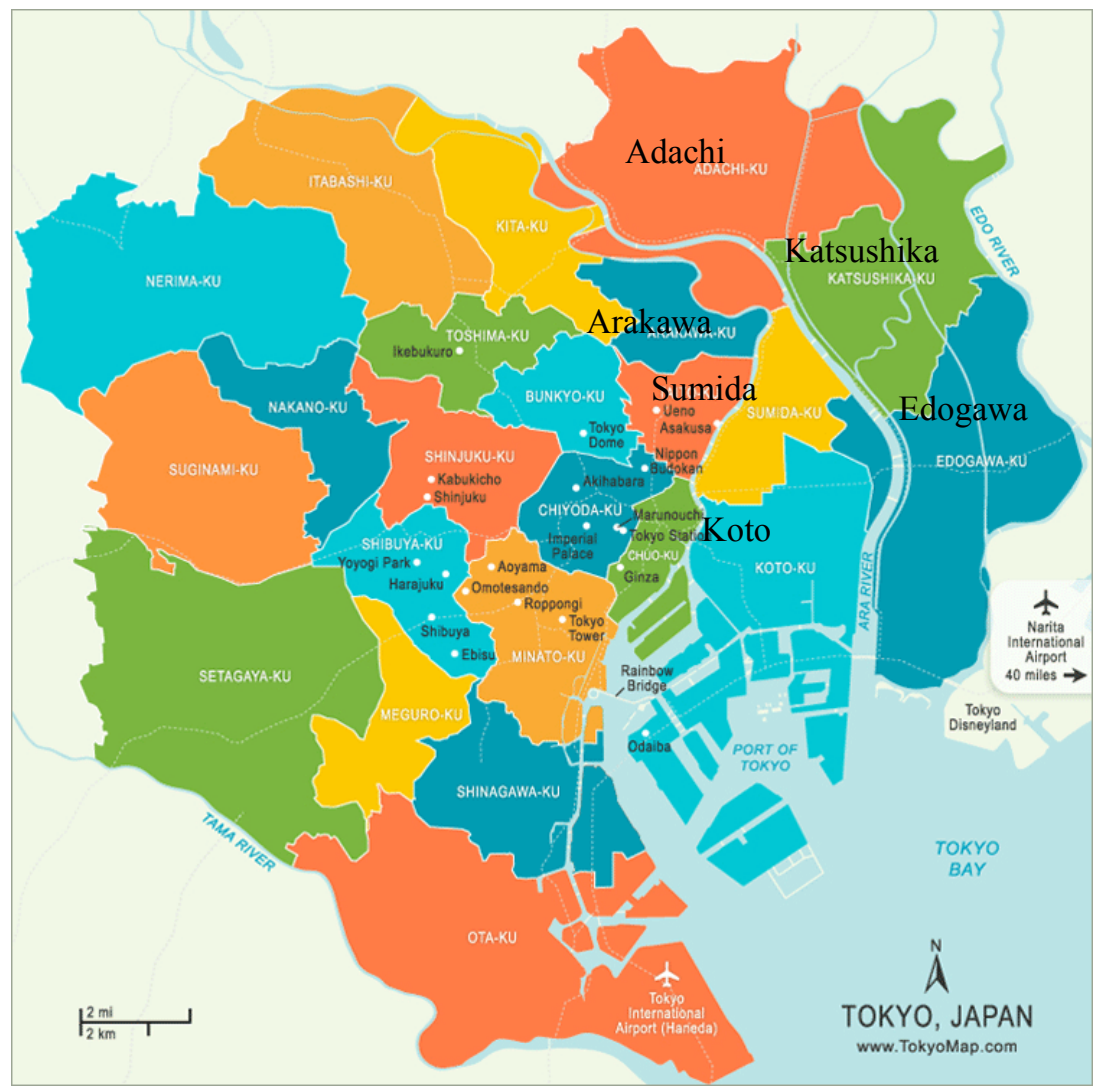

Figure 3: Map of central Tokyo [3].

Table 1: Population and number of households, by ward, in 2015 [4].

\begin{tabular}{|l|c|c|}
\hline Ward & Population & No. of households \\
\hline Arakawa & 209,087 & 108,564 \\
\hline Katsushika & 449,527 & 217,836 \\
\hline Adachi & 674,111 & 324,120 \\
\hline Edogawa & 680,262 & 322,827 \\
\hline Sumida & 258,423 & 139,014 \\
\hline Koto & 493,952 & 249,102 \\
\hline Tokyo Metropolis & $13,414,609$ & $6,890,789$ \\
\hline
\end{tabular}

Table 3 shows the number of pupils and teachers in elementary and junior high schools in the six wards of the Tokyo Metropolis in 2014, where the number in parentheses is the scholastic number [6]. About $20 \%$ of all elementary and junior high school pupils are studying in the lowlands of Tokyo. 
Table 2: $\quad$ Area and population density for the lowland areas in Tokyo [5].

\begin{tabular}{|l|c|c|}
\hline Ward & Area $\left(\mathrm{km}^{2}\right)$ & Population density $\left(\right.$ person $\left./ \mathrm{km}^{2}\right)$ \\
\hline Arakawa & 10.20 & $20,498.7$ \\
\hline Katsushika & 34.84 & $12,902.6$ \\
\hline Adachi & 53.20 & $12,671.2$ \\
\hline Edogawa & 49.86 & $13,644.0$ \\
\hline Sumida & 13.75 & $18,794.4$ \\
\hline Koto & 39.99 & $12,351.8$ \\
\hline Tokyo Metropolis & $2,188.67$ & $6,129.1$ \\
\hline
\end{tabular}

Table 3: Number of teachers and elementary and junior high school students [6].

\begin{tabular}{|l|rc|rr|r|}
\hline & \multicolumn{2}{|c|}{\begin{tabular}{|} 
Elementary \\
school students
\end{tabular}} & \multicolumn{2}{|c|}{$\begin{array}{c}\text { Junior high } \\
\text { school students }\end{array}$} & Teachers \\
\hline Arakawa Ward & 8,433 & $(24)$ & 4,329 & $(12)$ & 287 \\
\hline Katsushika Ward & 20,113 & $(49)$ & 9,552 & $(27)$ & 611 \\
\hline Adachi Ward & 31,322 & $(69)$ & 14,687 & $(39)$ & 935 \\
\hline Edogawa Ward & 35,334 & $(73)$ & 16,974 & $(35)$ & 968 \\
\hline Sumida Ward & 9,555 & $(25)$ & $5,413 \quad(13)$ & 343 \\
\hline Koto Ward & 22,552 & $(45)$ & 8,679 & $(25)$ & 565 \\
\hline Tokyo Metropolis & $592,158(1,351)$ & 310,874 & $(815)$ & 19,586 \\
\hline
\end{tabular}

Parentheses indicate the scholastic number.

A contour map of the Tokyo Metropolitan area is shown in Figure 4 [7]. The Arakawa, Katsushika, Adachi, Edogawa, Sumida and Koto wards are below the high water level (+2 m A.P.), where A.P. is the Arakawa Peil. Therefore, these areas are at risk from storm surges.

In Japan, kindergartens are provisioned under the School Education Law under the jurisdiction of the Ministry of Education, Culture, Sports, Science and Technology. Nursery schools are regulated by the Child Welfare Law of the Ministry of Health, Labor and Welfare. The number of kindergartens and nursery schools in the lowlands of Tokyo and the Tokyo Metropolis is shown in Table 4. The number of kindergartens and nursery schools in Japan is about 37,400, and the number of children in kindergartens and nursery schools is about 3,757,000 in 2014. The number of kindergartens and nursery schools in the Tokyo Metropolis is about 3,000, and the number of children is about 374,000 in 2014. The number of kindergartens and nursery schools in the lowlands is 641, and the number of children in kindergartens and nursery schools in the lowlands is 83,375 as shown in Table 4 [8]. 


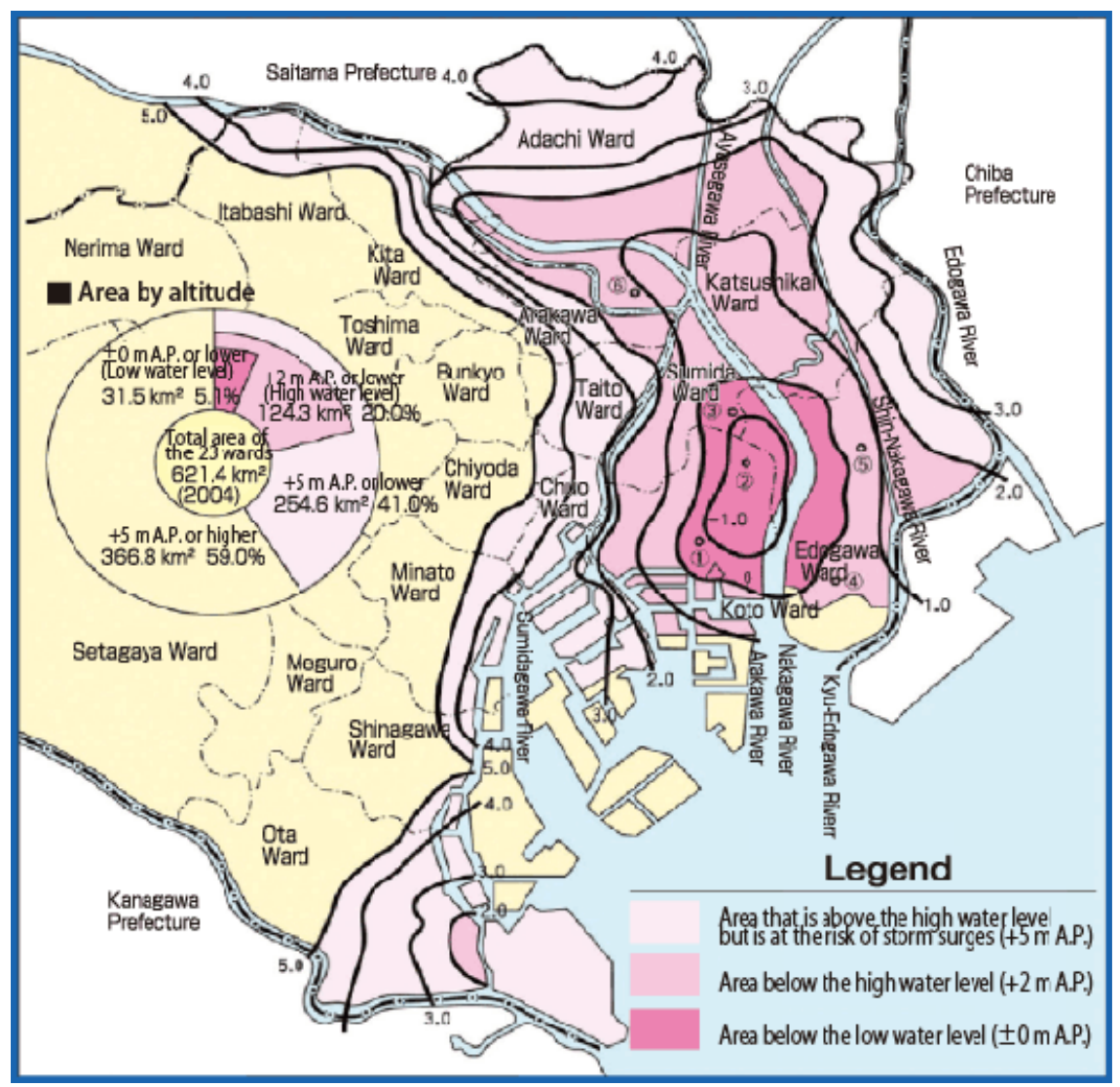

Figure 4: Contour map of the lowlands of Tokyo [7].

Table 4: Number of children attending kindergarten and nursery school in the Tokyo lowlands [8].

\begin{tabular}{|l|c|c|c|c|}
\hline & $\begin{array}{c}\text { No. of } \\
\text { kindergartens }\end{array}$ & $\begin{array}{c}\text { No. of } \\
\text { children in } \\
\text { kindergartens }\end{array}$ & $\begin{array}{c}\text { No. of } \\
\text { nursery } \\
\text { schools }\end{array}$ & $\begin{array}{c}\text { No. of } \\
\text { children in } \\
\text { nursery } \\
\text { schools }\end{array}$ \\
\hline Arakawa & 14 & 1,152 & 37 & 4,148 \\
\hline Katsushika & 33 & 6,454 & 83 & 9,117 \\
\hline Adachi & 58 & 9,734 & 95 & 9,834 \\
\hline Edogawa & 46 & 11,284 & 84 & 10,123 \\
\hline Sumida & 16 & 1,835 & 50 & 4,131 \\
\hline Koto & 33 & 4,745 & 92 & 10,818 \\
\hline
\end{tabular}




\section{Disaster prevention education and present conditions}

Effective disaster prevention preparation in a school requires an assessment of the facilities and features of the surrounding area. The school also acts as a refuge for local inhabitants during a disaster. The current state of disaster prevention preparations for about 32,000 schools nominated as disaster refuges was investigated with a questionnaire by the Japanese National Institute for Educational Policy Research in 2013 [9]. The results are as follows:

1) The shared role of the Board of Education and the Disaster Prevention Bureau is clearly defined in disaster prevention plans. (66\%).

2) The school has been designated as, or is considering becoming, a refuge. $(56 \%)$.

3) Plans for the use of school facilities when the school is being used as a refuge have been created. $(43 \%)$.

4) Storage facilities for food and medicine are installed in the school (42\%).

5) Restrooms which can be used by local residents (other than pupils) are installed at the school (69\%).

6) A restroom is installed in the gymnasium of the school (81\%).

7) Emergency communication equipment is installed in the school (47\%).

8) Electricity generators, for use in blackouts, are installed in the school (34\%).

9) Water tanks and water purification systems are installed in the school $(35 \%)$.

Flood control measures were also investigated for 44 elementary and 40 junior high schools in the Tokyo lowlands in 2013 as part of the investigation of the Japanese National Institute for Educational Policy Research.

The contents of the survey are as follows:

1) How many pupils are in your school?

2) How many teachers are in your school?

3) When was your school founded?

4) When were the school buildings constructed?

5) How many stories are the school buildings?

6) What is the total area of the school grounds?

7) Is there a flood evacuation site on campus?

8) For how many days food and water supplies are stored on campus?

9) What pharmaceutical supplies are stored on campus?

10) What is the distance from the school to the designated disaster refuge?

11) Is the refuge location clearly communicated to all staff and students?

12) Do you think that the evacuation site is safe in the event of a disaster?

13) Can the school building accommodate evacuees during a flood?

14) Has the school been affected by flooding?

15) Have you felt in danger due to flooding while at the school?

16) Is there a flood measures manual in the school?

17) Have roles been allocated for staff in flood situations at the school?

18) Does the school have sufficient sandbags to protect the facilities during a flood? 
19) Are electricity generators kept in the school?

20) How many times a year do you hold disaster drills?

21) Please include any additional comments.

The main results of the questionnaire are shown in Table 5.

Table 5: Results of questionnaires for elementary and junior high schools.

\begin{tabular}{|c|c|}
\hline Question & Answer \\
\hline 1) & $98-1,300$ pupil \\
\hline 2) & $15-60$ teachers \\
\hline 3) & $1874-2010$ \\
\hline 4) & $3-67$ years \\
\hline 5) & $3-8$ stories \\
\hline 6) & $120-1,369,337 \mathrm{~m}^{2}$ \\
\hline 7) & (yes) 34 schools, $\quad$ (no) 21 schools, (no answer) 9 schools \\
\hline 8) & 1-21 days, (no storage) 22 schools, (no answer) 4 schools \\
\hline 9) & $15-2000$ persons, (no storage) 31 schools, (no answer) 20 schools \\
\hline 10) & $\begin{array}{l}(0 \mathrm{~km}) 26 \text { schools, } \quad(0.1-0.5 \mathrm{~km}) 16 \text { schools, } \\
(0.6-1.0 \mathrm{~km}) 18 \text { schools, } \quad(1.1 \mathrm{~km} \text { or over }) 8 \text { schools }\end{array}$ \\
\hline 11) & (yes) 69 schools $(82 \%), \quad$ (no) 15 school $(18 \%)$ \\
\hline 12) & (yes) 38 schools $(45 \%), \quad$ (no) 46 schools $(55 \%)$ \\
\hline 13) & (yes) 52 schools $(62 \%)$ \\
\hline 14) & (yes) 4 schools $(5 \%), \quad$ (no) 80 schools $(95 \%)$ \\
\hline 15) & (yes) 10 schools $(12 \%)$ \\
\hline 16) & (yes) 43 schools $(51 \%)$ \\
\hline 17) & (yes) 46 schools $(55 \%), \quad$ (no) 38 schools $(45 \%)$ \\
\hline 18) & (yes) 4 schools $(5 \%), \quad$ (no) 80 schools $(95 \%)$ \\
\hline 19) & (yes) 58 schools $(69 \%)$ \\
\hline 20) & $\begin{array}{l}\text { ( } 1-5 \text { times/year) } 20 \text { schools, (6-10 times/year) } 19 \text { schools, } \\
(>10 \text { times/year) } 45 \text { schools }\end{array}$ \\
\hline 21) & $\begin{array}{l}\text { (1) It is important to have a system for mutual assistance between } \\
\text { the school and the residents association. } \\
\text { (2) It is necessary to increase the frequency of drills. } \\
\text { (3) The amount of food and medicine being stored should be } \\
\text { increased. } \\
\text { (4) Supplies should be stored in the loft. } \\
\text { (5) The school should be a high building. }\end{array}$ \\
\hline
\end{tabular}

A survey of flood control measures was also conducted for 91 preschools in 2013.

The questionnaire is as follows;

1) When was the school building constructed?

2) How many employees does the school have?

3) How many children are registered here?

4) How many stories high is the school building?

5) What is the function of each floor of the building?

6) What is the average age of employees? 
7) Has the building been damaged due to flooding?

8) Is there a flood response manual?

9) Do you have flood insurance?

10) Have roles been allocated for flood situations at the school?

11) Was the evacuation site selected with reference to a hazard map?

12) Do you think about evacuation procedures?

13) Is there a refuge near the building?

14) Have measures to prevent flood inundation been taken?

15) Is an electricity generation device installed?

16) Do you carry out drills?

17) Is there a reconstruction plan?

18) Is there hope of the moving to avoid a disaster?

19) Is there cooperation with the local authorities?

20) Are there supplies such as bedclothes or food?

21) Are lines of communication with the children's parents or guardians firmly established in the event of a disaster? If so, what plans have been made?

22) Do you provide psychological support to the children after the occurrence of a disaster?

The responses to the questionnaire are shown in Table 6.

Table 6: Response to the questionnaire for preschools.

\begin{tabular}{|c|c|}
\hline Question & Answer \\
\hline 1) & 1-59 years. (Average) 20.6 years \\
\hline 2) & 15-100 teachers. (Average) 32.4 teachers \\
\hline 3) & 30-197 children. (Average) 100.4 children \\
\hline 4) & (Average) 4.5 stories \\
\hline 5) & $\begin{array}{l}\text { (lower floor) preschool } \\
\text { (upper floor) teacher's room, school office, locker room, etc. }\end{array}$ \\
\hline 6) & 25-49 years old, (Average) 36.3 years old \\
\hline 7) & (yes) 3 schools ( 3\%), \\
\hline 8) & (yes) 44 schools $(48 \%)$ \\
\hline 9) & (yes) 34 schools $(37 \%)$ \\
\hline 10) & (yes) 88 schools $(97 \%)$ \\
\hline 11) & (yes) 80 schools $(88 \%)$ \\
\hline 12) & (yes) 7 schools ( 8\%), \\
\hline 13) & (yes) 84 schools $(92 \%)$ \\
\hline 14) & $\begin{array}{l}\text { (yes) } 32 \text { schools }(35 \%), \quad \text { (no) } 59 \text { schools }(65 \%) \\
\text { For example: (1) to take refuge on the top floor } \\
\text { (2) to take refuge on a neighboring high building } \\
\text { (3) to move the preserved food to the upper floors }\end{array}$ \\
\hline 15) & (yes) 11 schools $(12 \%), \quad$ (no) 80 schools $(88 \%)$ \\
\hline 16) & (yes) 89 schools $(98 \%)$ \\
\hline 17) & (yes) 13 schools $(14 \%)$ \\
\hline 18) & (yes) 1 school $(1 \%)$ \\
\hline 19) & (yes) 65 schools (71\%), \\
\hline
\end{tabular}


Table 6: Continued.

\begin{tabular}{|c|c|}
\hline Question & Answer \\
\hline 20) & $\begin{array}{ll}(\text { yes) } 90 \text { schools }(99 \%), & \text { (no) } 1 \text { school ( } 1 \%)\end{array}$ \\
\hline 21) & $\begin{array}{l}\text { (yes) } 87 \text { schools }(95 \%), \quad \text { (no) } 4 \text { schools ( } 5 \%) \\
\text { Methods for communication: } \\
\text { (1) Emergency group e-mail } \\
\text { (2) Construction of an emergency communication system } \\
\text { (3) Emergency contact number Telephone given priority to a } \\
\text { disaster } \\
\text { (4) Urgent network } \\
\text { (5) Reliable safe mail, etc. }\end{array}$ \\
\hline 22) & (yes) 48 schools $(52 \%)$ \\
\hline
\end{tabular}

The questionnaires presented here contain suggestions for improving disaster preparedness. For example, periodic disaster response drills with the local community, establishment of refuges or shelters, improved exchange of information, and storing of sufficient food and medical supplies.

Figure 5 is an elementary school and Figure 6 is a preschool near the river.

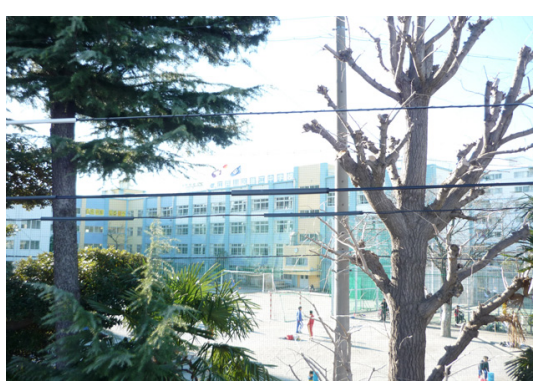

Figure 5: Elementary school.

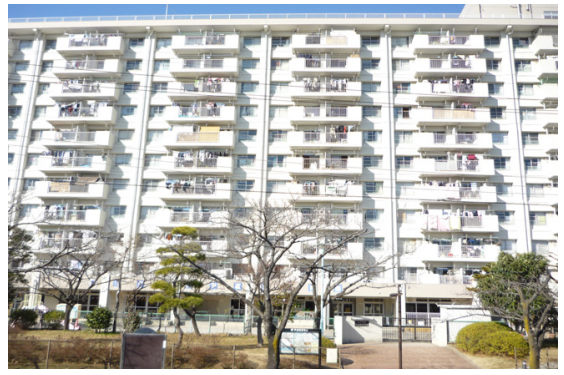

Figure 6: Preschool.

Figures 5 and 6 show an elementary school and a preschool located at the lowland in Tokyo. The elementary school is 5 stories and there is a field of refuge at neighboring place. The preschool is 11 stories and the floors above 2 stories are offices, homes, meeting rooms, etc., therefore they can be used for an emergency refuge at flooding hazards temporarily.

\section{Conclusions}

In the past, the lowlands of Tokyo were often affected by flooding. However, many flood measures have been put in place by the Tokyo Metropolitan and the national governments. 
There are many students studying in the Tokyo lowlands. These children are vulnerable to natural disasters. Therefore, teachers and parents must help protect the children from these disasters. Disaster education is useful for this purpose, as it helps raise awareness of the risk from disasters. As well as disaster education, disaster response measures must be established. Such measures include, for example, communicating the location of refuges and establishing communication networks among schools, families, and local authorities.

Communities play a vital role in the response to a disaster. In particular, residents associations can assist with disaster planning and preparation within each community. As shown by the questionnaire results, many schools are unaware of appropriate disaster prevention and response measures. The national and local governments should increase the budget for disaster prevention measures to improve the resilience of schools. Also, schools should provide disaster prevention education to raise awareness. Schools must establish emergency lines of communication with the parents and guardians of students, as well as with disaster medical assistance teams. Moreover, it is important to ensure there are sufficient emergency supplies being stored.

Since the Great East Japan Earthquake in 2011, various plans for disasters have been announced. The national and local government must think about improving disaster resilience, including the construction of high buildings and the relocation schools and evacuation sites.

\section{References}

[1] T. Katada, J. Asada and Y. Oikawa, School education and tradition about flood hazards in past influence for the feeling of disaster and the react to residents. http://dsel.ce.gunma-u.ac.jp/doc/p032.pdf (2016/1/30)

[2] Bureau of Construction, Tokyo Metropolitan Government, River Management and Utilization, http://www.kensetsu.metro.tokyo.jp/English /index.html (2016/1/30)

[3] http://www.tokyomap.com/ (2016/1/30)

[4] Tokyo Metropolitan Government, The population of the Tokyo Metropolis, http://www.toukei.metro.tokyo.jp/jsuikei/js-index.htm (2016/1/30)

[5] Tokyo Metropolitan Government, Tokyo statistical yearbook 2012, http://www.toukei.metro.tokyo.jp/tnenkan/2012/tn12q3i001.htm (2016/1/30)

[6] Bureau of Construction, Tokyo Metropolitan Government, River improvement in lowland areas, http://www.kensetsu.metro.tokyo.jp /english/index.html_(2016/1/30)

[7] Tokyo Metropolitan Government, School basic survey-Statistics of Tokyo Metropolis, http://www.toukei.metro.tokyo.jp/gakkou/gk-index.htm

[8] Tokyo Metropolitan Government, The setting situation of the nursery school, http://www.metro.tokyo.jp/INET/CHOUSA/2011/07/6017e401.htm

[9] National Institute for Educational Policy Research, The result of investigation into the actual conditions about disaster prevention of school facilities, http://www.mext.go.jp/b_menu/shingi/chousa/shisetu/013/007/ shiryo/_(2016/1/30) 